EUROPA REGIONUM TOM XXVIII ROK 2016

DOI: $10.18276 /$ er.2016.28-18

\author{
Zbigniew Piepiora, Magdalena Ewelina Godlewska \\ Uniwersytet Przyrodniczy we Wrocławiu
}

\title{
Ekonomiczna wartość bezpieczeństwa na szlakach turystycznych na Rysy, Giewont i na Orlej Perci
}

\section{Wprowadzenie}

$\mathrm{N}$

a kilkunastu odcinkach szlaków turystycznych w Tarach występują sztuczne ułatwienia w postaci łańcuchów, klamer czy drabinek. Są to m.in. szlaki na Rysy, Giewont czy Orlą Perć. Mimo istnienia wymienionych ułatwień od 1909-2014 r. w Tatrach zginęły 872 osoby. Z tego na Orlej Perci i szlakach dojściowych zginęły 122 osoby. W latach 1994-2014 na Orlej Perci i szlakach dojściowych doszło do 350 wypadków, w wyniku których zginęło 57 osób (Orla Perć... 2016).

W 1932 r. zamknięto odcinek Orlej Perci od Przełęczy Krzyżne do Polany pod Wołoszynem. Obecnie, m.in. na odcinku Zawrat-Krzyżne Orlej Perci i na szlaku przez kopułę szczytową Giewontu Tatrzański Park Narodowy wprowadził ruch jednokierunkowy, a jego słowacki odpowiednik - Tatranský Národný Park na szlaku na Rysy zastąpił łańcuchy stalowymi schodami (Słowacy... 2016).

TPN wraz z Tatrzańskim Ochotniczym Pogotowiem Ratunkowym zaleca także odpowiednie przygotowanie się do przejścia Orlej Perci i stosowanie na tym szlaku sprzętu do autoasekuracji - zestaw kask, lonża i uprząż (Piepiora 2015) i wpinanie się do sztucznych ułatwień. TPN jak na razie nie zdecydował się na likwidację wszystkich ułatwień na tym szlaku i pozwolenie na wejście tylko z przewodnikami czy też na likwidację łańcuchów i wprowadzenie ułatwień typu via ferrata (Orla Perć... 2016). 
Rozpatrując ten drugi wariant, autorzy postanowili wycenić wartość bezpieczeństwa na szlakach na Giewont, Rysy i na Orlej Perci. Znając tę wartość można ją porównać z kosztami likwidacji łańcuchów na rzecz wprowadzenia ułatwień na wymienionych szlakach i ocenić, czy inwestycja taka jest opłacalna. Celem artykułu jest więc wyznaczenie wartości bezpieczeństwa na szlakach turystycznych na Giewont, Rysy i na Orlej Perci. Autorzy wykorzystują do tego metodę wyceny warunkowej.

\section{Obszar, przedmiot i metoda badań}

Tatry są pasmem górskim wchodzącym w skład Karpat. Leżą na pograniczu Polski i Słowacji. Obszar jaki zajmują całe Tatry to $785 \mathrm{~km}^{2}$, przy czym tylko $175 \mathrm{~km}^{2}$ przypada po stronie Polski i są to jedyne góry o charakterze alpejskim w naszym kraju. Tatry dzielą się na Tatry Wysokie i Tatry Zachodnie. Podział wynika z wysokości i rzeźby terenu (Tatry.info.pl 2015; Godlewska 2016). Zarówno po stronie Polski jak i Słowacji Tatry wchodzą w skład Parków Narodowych obydwu państw. Teren TPN leży na obrębie czterech gmin: Zakopanego, Kościeliska, Poronina i Bukowiny Tatrzańskiej (Kulczyk-Dynowska 2014). W niniejszym artykule skupiono się tylko na obszarze polskiego Tatrzańskiego Parku Narodowego, który w 2015 r. odwiedziło 3309507 osób (Tatrzański Park Narodowy, www.tpn.pl, 10.03.2016).

Przedmiotem badania ekonomiczna wartość bezpieczeństwa na szlakach na Giewont, Rysy i na Orlej Perci. Autorzy wykorzystują do jej oszacowania metodę wyceny warunkowej.

Metoda wyceny warunkowej (ang. Contingent Valuation - CV) bazuje na preferencjach respondentów oraz ich potrzebie na istnienie czystego środowiska przyrodniczego. W sposobie tym zakłada się, że ludzie wiedzą najlepiej co dla nich jest najbardziej racjonalne i czego potrzebują. Wycena metodą warunkową odbywa się przez przeprowadzenie ankiet i zebranie informacji ile ludzie są w stanie zapłacić, by nie utracić cennego dla nich środowiska. Badani są informowani na początku o hipotetycznym zagrożeniu dobra ekologicznego, bądź też całkowitej utracie dostępu do niego. Następnie pytani są o gotowość do zapłaty za utrzymanie dobra $\mathrm{w}$ stanie niepogorszonym $\mathrm{z}$ dostępem do korzystania $\mathrm{z}$ niego lub możliwość rekompensaty za utratę cennego środowiska bądź pogorszenie się jego stanu (Becla A., Czaja S. i Zielińska A. Analiza kosztów-korzyści w wycenie środowiska przyrodniczego 2012). 
Wykorzystując gotowość do zapłaty (WTP) respondenci są proszeni o wskazania maksymalnej kwoty jaką są w stanie ponieść np. w postaci podatku na rzecz środowiska przyrodniczego. Używając zaś gotowość do akceptacji rekompensaty (WTA) proszeni są o wskazanie najmniejszej wartości dla której byli by skłonni utracić dobro przyrodnicze (Willpenny, Wartość środowiska, 1995, s. 91-97; J. Famielec, Straty i korzyści ekologiczne w gospodarce narodowej 1999).

Wzór 1. Wzór na gotowość do zapłaty

$\mathrm{W}_{\text {WTP }}$ - łączna wartość WTP,

$$
W=\left(\frac{W_{W T P}}{n}\right) \times L
$$

n - liczba osób, które chcą zapłacić,

$\mathrm{L}$ - roczna liczba osób odwiedzających park.

Źródło: A. Zydroń, A. Sikora, Wycena wartości Parku Sołackiego w Poznaniu metoda wyceny warunkowej, w: Studia i prace wydziatu nauk ekonomicznych i zarzadzania, nr 42, t. 2.

Wzór 1. Renta wieczysta (perpetuita)

PV - wartość obecna,

$$
P V=\frac{A}{r}
$$

A - wysokość raty,

$\mathrm{r}$ - stopa procentowa.

Źródło: T. Kołakowski, Wybrane zagadnienia analizy i oceny ekonomicznej projektów inwestycyjnych, Wydawnictwo. UE, Wrocław 2014.

Autorzy postanowili wykorzystać tę metodę do wyceny wartości bezpieczeństwa na kilku z trudniejszych szlaków występujących w Tatrzańskim Parku Narodowym na takie szczyty jak Giewont, Orlą Perć i Rysy. Pytanie dotyczące wyceny bezpieczeństwa jest otwarte. Występuje po pytaniu, za którą z możliwych propozycji poprawy bezpieczeństwa respondenci oponują. Jedną z opcji jest wprowadzenie odpowiedniej opłaty za wejście na owe szlaki. Pieniądze z tej opłaty przeznaczone byłyby na poprawę zabezpieczeń na szlakach np. na likwidację łańcuchów i wprowadzenie ułatwień typu via ferrata. Gdy badani opowiedzą się za tą formą mają do wyboru zaproponowane odgórnie 4 kwoty: 50, 20, 10 lub 5 zł bądź inną wybraną przez siebie kwotę.

Otrzymany wynik ze wzoru (1) należy podstawić do wzoru (2), z którego otrzyma się bieżącą wartość środowiska przy wybranej stopie procentowej, w cenach z bieżącego roku. Przy czym warto zwrócić uwagę, że jest to wariant 
uproszczony wyceny za pomocą $\mathrm{CV}$, względem np. budowy modelu logitowego czy probitowego.

\section{Badania ankietowe}

Badania ankietowe przeprowadzono w okresie październik 2015 - maj 2016 (Żylicz 2016). Warto zauważyć, że ze względy na brak inflacji w roku 2014 i na występującą niewielką deflację - autorzy założyli stały poziom cen w latach 2014-2016 (Roczne... 2016).

Badania ankietowe podzielono na 3 próby: próba ankiet przeprowadzona na turystach bezpośrednio przebywających w Tatrzańskim Parku Narodowym, próba kolejowa (ankietowanie podczas jazdy pociągiem) oraz internetowa. W próbie terenowej wzięto pod uwagę 48 odpowiedzi (5 osób mieszkało bądź pracowało na terenie TPN, toteż zostali pominięci, ze względu na brak ponoszonych kosztów w celu dotarcia do TPN). Podczas jazdy pociągiem ankietę przeprowadzono wśród 58 osób. W próbie internetowej. wzięło udział 247 osób

Rozpatrzono pięć elementów do scharakteryzowania respondentów. Pierwszym jest określenie liczby turystów biorących udział w badaniu ze względu na województwo, z którego przyjeżdżają do Tatrzańskiego Parku Narodowego.

Dostrzeżono, iż największy procent turystów pochodził $\mathrm{z}$ województwa małopolskiego (24\%) i wynosi dla: próby terenowej - 34\%, próby kolejowej $19 \%$, próby internetowej - 23\%. Drugim województwem pod względem dużej liczby turystów było województwo śląskie (15\%): próba terenowa i internetowa - 15\%, próba kolejowa - 16\%. Trzecim województwem, które łącznie we wszystkich próbach uzyskało $13 \%$ było województwo dolnośląskie. Warto zauważyć, że odległość tych trzech województw w stosunku do Tatrzańskiego Parku Narodowego jest dosyć mała, a infrastruktura drogowa i techniczna pomiędzy nimi jest wysoko rozwinięta. Ułatwieniem $\mathrm{w}$ dotarciu ludzi do TPN z tych województw była spora ilość połączeń kolejowych i autobusowych oraz autostrada A4. Fakty te przyczyniły się do tego, że wśród ogółu respondentów najwięcej jest $\mathrm{z}$ wymienionych województw: małopolskiego, śląskiego i dolnośląskiego. Wpływ na to miała także ilość ludzi mieszkająca w tych województwach. Wszystkie trzy należą do pierwszej piątki województw w Polsce pod względem liczby ludności. Wart uwagi jest fakt taki, iż w badaniu internetowym wzięły udział 4 osoby z zagranicy (Ludność... 2016) poza uczestnikami ze wszystkich polskich województw. 
Kolejny element, który wzięto pod uwagę, to podział badanych ze względu na ich wiek. Szczegółowe dane zamieszczone zostały w tabeli 1.

Tabela 1

Liczba turystów biorących udział w badaniu z podziałem na wiek

\begin{tabular}{|l|r|r|r|r|}
\hline \multirow{2}{*}{ Wiek } & \multicolumn{4}{|c|}{ Liczba turystów } \\
\cline { 2 - 5 } & próba terenowa & próba kolejowa & próba internetowa & łącznie \\
\hline Do 24 lat & 19 & 24 & 91 & 134 \\
\hline $25-34$ & 18 & 17 & 93 & 128 \\
\hline $35-44$ & 7 & 9 & 41 & 57 \\
\hline $45-54$ & 5 & 6 & 13 & 24 \\
\hline $55-64$ & 4 & 2 & 7 & 13 \\
\hline 65 lat i więcej & 0 & 0 & 2 & 2 \\
\hline Suma & 53 & 58 & 247 & 358 \\
\hline
\end{tabular}

Rozpatrując tabelę 1, można stwierdzić, że największy udział w badaniu miały osoby młode do 24 lat łącznie $37 \%$. Osoby do 24 roku życia dominowały w próbie kolejowej. Wpływ na to miało to, że przejazdy PKP ze względu na ulgi w cenach biletów, są głównym sposobem transportu ludzi młodych. Drugą znaczącą grupę w badaniu stanowily osoby między 25 a 34 rokiem życia (36\%). Najmniej, bo zaledwie $0,56 \%$ stanowili ludzie powyżej 65 roku życia. Taki rozkład procentowy respondentów ze względu na wiek jest słuszny, ponieważ największy procent w Polsce stanowią ludzie w wieku produkcyjnym, zaś najmniejszy poprodukcyjnym (Struktura... 2016), ponadto ze względu na fakt, iż Tatrzański Park Narodowy jest terenem górzystym, trudno dostępnym dla ludzi starszych. Natomiast ludzie młodzi, w tzw. kwiecie wieku są bardzo ciekawi i chętni na zwiedzanie i podróże, także w trudniej dostępne miejsca.

W tabeli 2 przedstawiono podział turystów Tatrzańskiego Parku Narodowego przez wzgląd na ich wykształcenie. Udział osób ze względu na wykształcenie był ważny, ponieważ inaczej TPN i ochronę przyrody będzie postrzegać osoba, która nie jest świadoma jej znaczenia i zagrożeń, a inaczej osoba, na przykład $\mathrm{z}$ wykształceniem $\mathrm{w}$ kierunku ochrony środowiska i kształtowania przestrzeni.

Analizując tabelę 2, można zauważyć, że największą grupę w każdej próbie stanowili ludzie z wykształceniem średnim (łącznie 41\%), niewiele mniej (39\%) było ludzi z wykształceniem wyższym. Najmniej, bo zaledwie 2\% ogółu badanych, posiadało wykształcenie podstawowe. Warto zauważyć, że podobnie sytuacja wygląda z wykształceniem ludzi w Polsce (Polski... 2016). Taki rozkład procentowy, 
wskazuje na to, iż ludzie wykształceni mają większą potrzebę podróżowania i odpoczynku w naturalnym i cennym krajobrazie jakim jest TPN.

Liczba turystów biorących udział w badaniu z podziałem na wykształcenie

\begin{tabular}{|l|c|c|c|c|}
\hline \multirow{2}{*}{ Wiek } & \multicolumn{4}{|c|}{ Liczba tury stów } \\
\cline { 2 - 5 } & próba terenowa & próba kolejowa & próba internetowa & łącznie \\
\hline Podstawowe & 1 & 2 & 5 & 8 \\
\hline Gimnazjalne & 3 & 2 & 8 & 13 \\
\hline Zasadnicze-zawodowe & 5 & 7 & 37 & 49 \\
\hline Srednie & 24 & 24 & 101 & 149 \\
\hline Wyższe & 20 & 23 & 96 & 139 \\
\hline Suma & 53 & 58 & 247 & 358 \\
\hline
\end{tabular}

W tabeli 3 ukazano podział ankietowanych ze względu na stopień ich zatrudnienia. Autorzy uwzględnili te dane, gdyż zatrudnienie jak i zarobki miały ogromny wpływ na możliwości odwiedzenia Tatrzańskiego Parku Narodowego.

Tabela 3

Liczba turystów biorących udział w badaniu ze względu na status zatrudnienia

\begin{tabular}{|l|c|c|c|c|}
\hline \multirow{2}{*}{ Wykształcenie } & \multicolumn{4}{|c|}{ Liczba turystów } \\
\cline { 2 - 5 } & próba terenowa & próba kolejowa & próba internetowa & łącznie \\
\hline Zatrudniony & 21 & 20 & 124 & 165 \\
\hline Bezrobotny & 3 & 2 & 3 & 8 \\
\hline Uczeń/Student & 23 & 27 & 109 & 159 \\
\hline Emeryt/Rencista & 5 & 7 & 6 & 18 \\
\hline Inne & 1 & 2 & 5 & 8 \\
\hline Suma & 53 & 58 & 247 & 358 \\
\hline
\end{tabular}

Rozpatrując tabelę 3 można stwierdzić, że osoby zatrudnione stanowią największą grupę w badanej populacji, łącznie $46 \%$. Zaraz po niej uplasowali się studenci i uczniowie, stanowiący $42 \%$. Najmniej, bo tylko $2 \%$ stanowiła grupa osób bezrobotnych i udzielających odpowiedzi na temat swojego zatrudnienia jako ,inne". Potwierdza to opinię autorów, że osoby zatrudnione mają możliwości zwiedzania TPN ze względu na to, iż są osobami zarabiającymi isą w stanie, w miarę możliwości, pozwolić sobie na taką podróż. Studenci i uczniowie mają zaś więcej czasu wolnego, który ochoczo spędzają na wyjazdach.

W tabeli 4 przedstawiono dochód miesięczny w złotych na osobę w gospodarstwie domowym podróżującego. Warto zauważyć, że przeciętny dochód miesięczny na osobę w Polsce w roku 2015 wyniósł 1386 zł (Obwieszczenie... 2016), zaś w rok wcześniej był o 46 zł mniejszy. Analizując tabelę 4 wywnio- 
skowano, iż dochód respondentów był dość równo rozłożony powyżej i poniżej przeciętnego poziomu dochodu.

Tabela 4

Liczba turystów biorących udział w badaniu z uwzględnieniem dochodu miesięcznego na 1 osobę (w zl).

\begin{tabular}{|l|c|c|c|c|}
\hline \multirow{2}{*}{ Dochód miesięczny } & \multicolumn{4}{|c|}{ Liczba tury stów } \\
\cline { 2 - 5 } & próba terenowa & próba kolejowa & próba internetowa & łącznie \\
\hline Poniżej 750 zł & 11 & 8 & 37 & 56 \\
\hline $750 \mathrm{zł}-1249 \mathrm{zł}$ & 18 & 20 & 63 & 101 \\
\hline $1250 \mathrm{zl}-1749 \mathrm{zł}$ & 7 & 11 & 47 & 65 \\
\hline $1750 \mathrm{zl}-2249 \mathrm{zł}$ & 6 & 4 & 36 & 46 \\
\hline $2250 \mathrm{zł} \mathrm{i} \mathrm{powyżej}$ & 11 & 15 & 64 & 90 \\
\hline Suma & 53 & 58 & 247 & 358 \\
\hline
\end{tabular}

Dodatkowe badania ankietowe (próba internetowa) w celu określenia liczby wizyt na badanych szlakach turystycznych przeprowadzono $\mathrm{w}$ terminie 20.07-1.10.2016. Wypełniono 336 ankiet. Liczba wszystkich wizyt: 2128 w tym: Rysy: 162 (7,61\% spośród wszystkich zadeklarowanych wizyt), Giewont: 141 (6,63\%), Orla Perć: 154 (7,24\%). Po zsumowaniu liczby wejść na Rysy, Giewont i przejść przez Orlą Perć otrzymano 21,48\% w relacji do wszystkich zadeklarowanych wejść.

\section{Wartość bezpieczeństwa na szlakach na Giewont, Rysy i na Orlej Perci ustalona metodą wyceny warunkowej}

Respondenci po zapoznaniu się z krótką informacją na temat wypadków w Tatrach i sposobem poprawy bezpieczeństwa, jaki wprowadzili słowaccy sąsiedzi. Następnie padło pytanie, czy są za wprowadzeniem ograniczeń na szlakach turystycznych w celu poprawy bezpieczeństwa. W zależności od odpowiedzi odsyłani byli do dalszych pytań. Jeżeli opowiedzieli się za wprowadzeniem ograniczeń, pytani byli, za którymi z wymienionych lub też mogli wpisać w polu „,inne” własne zaproponowane rozwiązanie. Następnie ankietowani, którzy wybrali wprowadzenie dodatkowych opłat za wejście na trudniejsze szlaki proszeni byli o podanie kwot za jednorazowe wejście na taki szlak. Do wyboru mieli cztery z góry podane kwoty: 50, 20, 10 i 5 zł oraz możliwość podania własnej proponowanej kwoty.

Wśród ankietowanych, za wprowadzeniem ograniczenia przez uiszczanie opłaty za wejście na szlaki, przeznaczonej na poprawę i rozbudowę zabezpie- 
czeń szlaku opowiedziało się 138 osób. W tabeli 5 przedstawiono kwoty zaproponowane przez ankietowanych.

Tabela 5

Kwoty zaproponowane jako dodatkowa opłata za wejście na szlaki

\begin{tabular}{|c|c|}
\hline Kwota opłaty: & Liczba respondentów: \\
\hline 2 & 6 \\
\hline 2,5 & 2 \\
\hline 5 & 48 \\
\hline 10 & 59 \\
\hline 20 & 15 \\
\hline 50 & 8 \\
\hline
\end{tabular}

Rozpatrując tabelę 5, można stwierdzić, że najwięcej osób opowiedziało się za kwotą 10 zł (43\%), drugą kwotą, którą zaproponowało dużo osób było 5 zł (35\%). Tylko 2 osoby zaproponowały cenę $2,5 \mathrm{zk}$.

Łączna kwota opłat zaproponowanych przez ankietowanych wyniosła 1 546,98 zł, co dało średnio 11,21 zł po cenach z 2016 r. Aby obliczyć bezpieczeństwo na szlakach na Giewont, Rysy i Orlej Perci, przemnożono L ze wzoru pierwszego odpowiednio przez: $6,63 \%, 7,61 \%, 7,24 \%, 21,48 \%$.

Wartość bezpieczeństwa na szlaku na Giewont wyniosła:

$$
W=\left(\frac{W_{W T P}}{n}\right) \times L=\left(\frac{1546,98}{138}\right) \times 3309507 \times 6,63 \%=2459701,721(\mathrm{zl}) .
$$

Następnie otrzymaną kwotę podstawiono do wzoru na perpetuitę, zakładając stopę referencyjną na poziomie $1,5 \%$ (Podstawowe... 2016):

$$
P V=\frac{9,2459701,721437}{1,5 \%}=163980114,7 \text { (zł). }
$$

Wartość bezpieczeństwa na szlaku na Rysy wyniosła:

$$
W=\left(\frac{W_{W T P}}{n}\right) \times L=\left(\frac{1546,98}{138}\right) \times 3309507 \times 7,61 \%=2823277,541 \quad(\mathrm{zf}),
$$

zaś po podstawieniu do wzoru na perpetuitę z tą samą stopą referencyjną:

$$
P V=\frac{9,42823277,54137}{1,5 \%}=188218502,7 \text { (zł). }
$$

Wartość bezpieczeństwa na Orlej Perci wyniosła:

$$
W=\left(\frac{W_{W T P}}{n}\right) \times L=\left(\frac{1546,98}{138}\right) \times 3309507 \times 7,24 \%=2686009,119(\mathrm{zf}),
$$

a po podstawieniu do wzoru na rentę wieczystą, zakładając tę samą stopę referencyjną: 


$$
P V=\frac{9,42686009,11937}{1,5 \%}=179067274,6(\mathrm{zl}) .
$$

Wartość bezpieczeństwa na szlakach na Giewont, Rysy i na Orlej Perci wyniosła:

$$
W=\left(\frac{W_{W T P}}{n}\right) \times L=\left(\frac{1546,98}{138}\right) \times 3309507 \times 21,48 \%=7968988,381(\mathrm{zl}),
$$

a po podstawieniu do wzoru jak wyżej:

$$
P V=\frac{9,47968988,38137}{1,5 \%}=531265892,1 \quad(\mathrm{z}) .
$$

\section{Podsumowanie}

Celem artykułu było wyznaczenie wartości bezpieczeństwa na szlakach na Giewont, Rysy i na Orlej Perci. Autorzy wykorzystali do tego metodę wyceny warunkowej. Wartość bezpieczeństwa na szlaku na Giewont wyniosła blisko 164 miliony złotych, na Orlej Perci - 179 milionów zł, na szlaku na Rysy - 188 mln zł. Łączna wartość bezpieczeństwa na szlakach na Giewont, Orlą Perć i Rysy wyniosła nieco ponad $531 \mathrm{mln}$ złotych po cenach z 2016 roku.

Oznacza to, że jeżeli koszty likwidacji łańcuchów na rzecz wprowadzenia ułatwień typu via ferrata na wymienionych szlakach i ocenić poniżej wymienionych kwot są opłacalne.

\section{Bibliografia}

Becla A., Czaja S., Zielińska A., Analiza kosztów-korzyści w wycenie środowiska przyrodniczego, Wyd. Difin, Warszawa 2012.

Famielec J., Straty $i$ korzyści ekologiczne w gospodarce narodowej, Wydawnictwo PWN, Warszawa-Kraków 1999.

Giergiczny M., Kronenberg J., Jak wycenić wartość przyrody w mieście? Wycena drzew przyulicznych w centrum Łodzi, w: Zrównoważony Rozwój — Zastosowania nr 3, wyd. Fndacja Sendzimira, Warszawa 2012.

Godlewska E., Rekreacyjna wartość Tatrzańskiego Parku Narodowego, praca inżynierska przygotowana pod kierunkiem Z. Piepiora, WIKŚiG UP, Wrocław 2016.

Kołakowski T., Wybrane zagadnienia analizy i oceny ekonomicznej projektów inwestycyjnych, Wydawnictwo. UE we Wrocławiu, Wrocław 2014.

Kulczyk-Dynowska A., Turystyka w gminach tatrzańskich ze szczególnym uwzględnieniem roli Tatrzańskiego Parku Narodowego, w: Gospodarka lokalna w teorii i praktyce. Prace Naukowe Uniwersytetu Ekonomicznego we Wrocławiu nr 332, wyd. UE we Wrocławiu, Wrocław 2014.

Ludność wedlug województw, www.stat.gov.p1/statystyka-regionalna/rankingistatystyczne/ludnosc-wedlug-wojewodztw/, (dostęp 24.04.2016). 
Obwieszczenie $w$ sprawie przeciętnego miesięcznego dochodu rozporzadzalnego na 1 osobę ogółem w 2015 r., www.stat.gov.pl/sygnalne/komunikaty-i-obwieszczenia/ lis ta-komunikatow-i-obwieszczen/obwieszczenie-w-sprawie-przecietnegomiesiecznego-dochodu-rozporzadzalnego-na-1-osobe-ogolem-w-2015-r,294,2.html, (dostęp 24.04.2016).

Orla Perć - Bezpieczeństwo. Przygotowanie. Sprzęt, https://www.youtube.com/wa tch $? \mathrm{v}=\mathrm{oDyoWgKNpjE}$, (dostęp 1.11.2016).

Piepiora Z., Żelazna droga w Czeskim Raju, w: K. R. Mazurski (red.), Na szlaku, 12/2015, http:/www.na-s zlaku.net/.

Podstawowe stopy procentowe NBP www.nbp.pl/home.aspx?f=/dzienne/stopy.htm, (dostęp 1.05.2016).

Polski rynek pracy - aktywność zawodowa i struktura wykształcenia, www.uj.edu.p1/ documents/102715934/b78ab8e9-0daf-4cb7-9753-748201dce056, (dostęp 23.04.2016).

Roczne wskaźniki cen towarówi usług konsumpcyjnych od 1950 roku, http://stat.gov.pl/ obszary-tematyczne/ceny-handel/wskazniki-cen/wskazniki-cen-towarow-i-us lugkonsumpcyjnych-pot-inflacja-/roczne-wskazniki-cen-towarow-i-uslugkonsumpcyjnych-w-latach-1950-2014, (dostęp 10.06.2016).

Stowacy zbudowali schody na Rysy. Turyści pytaja, gdzie winda, http://www.polsatnews .pl/ wiadomosc/2016-09-02/slowacy-zbudowali-schody-na-rysy-turysci-pytajagdzie-winda/, (dostęp 2.09.2016).

Struktura ludności według wieku od 1970 r., www.stat.gov.p1/obszary-tematyczne/ ludnosc/ludnosc/ludnosc-piramida/, (dostęp 24.04.2016).

Tatry.info.pl, www.tatry.info.pl, (dostęp 15.12.2015).

Tatrzański Park Narodowy, www.tpn.pl, (dostęp 10.03.2016).

Willpenny J. T., Wartość środowiska, Wyd. PWN, Warszawa 1995.

Zydroń A., Sikora A., Wycena wartości Parku Solackiego w Poznaniu metoda wyceny warunkowej, w: Studia i prace Wydziału Nauk Ekonomicznych i Zarządzania nr 42, t. 2, Wydawnictwo US, Szczecin 2015.

Żylicz T., Czy warto przywrócić Battyk do życia? Studium przypadku, http://coin. wne.uw.edu.p1/tzylicz/case-6-CVM.pdf, (dostęp 24.10.2016).

\section{The economic value of safety on tourist routes to Rysy, Giewont and on Orla Perć (the Eagle's Path)}

\section{Summary}

We used the contingent valuation (CV) method to calculate the economic value of safety on tourist routes to Rysy, Giewont and on Orla Perć (the Eagle's Path). We conducted the study using a survey executed in three attempts: field work, railway and online. The value of safety on the route to Giewont amounted to nearly 164 million zt, on Orla Perć - 179 million zt, on the route to Rysy - 188 million zł. The total value of safety on routes to Giewont, Rysy and on Orla Perc amounted to just over 531 million zł indexed to the year 2016. 